DOI: $10.34185 / 1991-7848.2020 .01 .05$

UDK 004.272.43.003.13

V. Ivaschenko, G. Shvachych, M. Sazonova, O. Zaporozhchenko, V. Khristyan

\title{
METALS HEAT TREATMENT MODEL
}

This paper considers the problem of developing a model of thermal metal processing by multiprocessor computing systems. The obtained metal is used for high-strength fasteners manufactured by cold forging method without final heat treatment. The model is based on the heat treatment method of a billet from low-and medium-carbon steels intended for cold heading. The model aims at improving technological properties of a billet by ensuring high dispersion and uniformity of a billet structure across the entire plane of its cross-section.

Implementation of the proposed model ensures the technical result of high dispersion and uniformity of the structure of the billet. The technological process of steel heat treatment is characterized by high performance, low power consumption, and improved performance characteristics. The apparatus for implementation of the spheroidization annealing regime determines the uniform distribution of cementite globules in the ferrite matrix, which means that it provides the necessary mechanical properties of the metal for its further cold deformation. The multiprocessor computing system software allows controlling the temperature conditions, both on the entire plane of the billet section, and across its length. Such temperature conditions are controlled in the center of the plane of the billet cross-section.

Experimental studies of the heat treatment of metal products were conducted. In order to test the functions of the proposed model, several experiments were performed when a $20 \mathrm{~mm}$ diameter wire from $20 \mathrm{G} 2 \mathrm{G}$ steel was subjected to heat treatment. Experimental studies have shown that metal has the necessary elasticity properties, saving the required hardness.

Keywords: heat treatment, multiprocessor computing system, mathematical model, parameter control, technological process, temperature regime.

\section{Introduction}

Today in the world, there is a sharp increase in the number of multiprocessor computing systems and their performance by the fact that such systems have become widely available along with non-expensive hardware platforms for highperformance computing [1, 2]. It should be emphasized that there is a lot of diverse and interrelated processes in the metallurgical industry. Primarily, those technologies include smelting and casting of iron-carbon alloys, heating, rolling, and metal heat treatment (HT), as well as operation of auxiliary equipment, which includes filling machines, ladles, bowls, and others. Based on the industrial practice,

(C) Ivaschenko V., Shvachych G., Sazonova M., Zaporozhchenko O., Khristyan V., 2020 
there could be neither the intensification of processes of metallurgical manufacturing nor the constructive improvement of different metallurgical equipment without studying and analyzing the phenomena of heat and mass transfer [3 - 5]. High-performance computing allows solving multidimensional problems, and the ones that demand huge processing time. Control of speed enables not only to manage technological processes effectively but also to create preconditions for development of new promising technological processes.

\section{Analysis of recent research and publications}

The traditional technology of spheroidizing steel annealing involves cage furnaces (bell-type or shaft-type) [6,7]. The process includes heating the material to such a temperature value: $\mathrm{Ac}_{1}+(10-30)^{\circ} \mathrm{C}$; holding for 20-30 hours, followed by further delayed cooling. Besides, heat treatment (HT) of wire coils, for example, in shaft-type furnaces, is accompanied by significant temperature non-uniformity in load volume.

The traditional methods disadvantages of preparing metal for cold deformation:

1. The inability to synchronize the technological process of metal HT with the technological process of fasteners production.

2. Significant energy and gas losses during metal annealing in furnaces.

3. Poor furnace performance.

4. The difficulty of ensuring uniform heating and cooling of wire coils.

5. The furnaces for metal HT are environmentally harmful.

Progressive technologies that will fundamentally change the traditional lowproductive energy-intensive processes include the methods of rapid heating of metal (wire, rods) adapted to the conditions of hardware manufacturing. In this case, an HT method alternative to the furnace heating of products is the electrothermal method: electrical contact heating or induction [7]. In-line industrial introduction of induction heating for HT is practically well-known [9]. Usually, the thermally treated wire is used in the manufacture of high-strength fasteners without final thermal hardening.

At the same time, the described HT process for the technology of spheroidizing and recrystallization annealing has certain disadvantages, namely:

1. Lack of control of heating, holding, and cooling during metal HT.

2. The technological process of metal processing does not provide for spheroidizing annealing in the interval of perlite structural steel transformations.

3. The steel annealing mode provides for a considerable duration of the technological process (according to the authors, from 30 to 90 minutes), which does not allow synchronizing the closed cycle of manufacturing fasteners. 
Also, there are other approaches to the implementation of the proposed method, e.g., an installation for the calibrated steel HT [10]. The following disadvantages of the proposed installation in its application for spheroidizing annealing:

1. The installation did not realize capabilities of steel HT associated with application of annealing temperature range to acquire a spheroidizing perlite structure [11].

2. The steels annealing mode is characterized by a significant duration of the technological process.

3. There is no possibility to control the temperature of heating, holding, and cooling of steel within the billet section plane.

4. High energy intensity of the process.

\section{Statement of the Problem Research}

In this paper, the development of the latest metallurgical technologies based on the use of multiprocessor computing systems is illustrated based on billets HT. In this case, the billet for cold heading should have in the initial state the structure of granular perlite of a particular grade, i.e., such that has a globular form of a carbide phase of a specific size. In order to obtain the indicated structural condition, the preform is subjected to spheroidizing annealing.

This research's primary purpose is to develop an HT model of metals based on multiprocessor computing systems used for the manufacture of high-strength fasteners by cold die forging without final HT. It was decided for the model to apply the billet HT method with low- and medium-carbon steels intended for cold heading. The model application aims at improving the technological properties of a billet by ensuring high dispersion and uniformity of the billet structure over the entire plane of its cross-section.

\section{Statement of the Research's Primary Material}

In order to solve the outlined problems, the installation was designed for the HT of long steel products [12]. At the same time, researches aimed at studying the features of metal HT using such a setup have been considered in papers [13-15]. The developed installation is intended for the steel HT of billets and can be used for recrystallization and spheroidizing annealing of calibrated steel for the manufacture of fasteners by the cold die forging method.

The problems are solved because the installation for HT of a long steel product additionally contains isothermal holding cameras, intensive spheroidization devices, a multiprocessor computing complex in the form of a separate module. A multiprocessor computing system with its software allows, based on a mathematical model of the billet heating process, under the manufacturing conditions to control 
the product heating to the transition to the austenitic area towards the recrystallization phase temperature on the entire plane of its section, and then, having solved the inverse problem of thermal conductivity (IPTC), monitoring the required regime of isothermal holding in the annealing temperature range over the entire plane of the billet cross-section. The installation for implementing the regime of over-annealing determines the uniform distribution of cementite globules in a ferrite matrix, which provides the necessary metal mechanical properties necessary for further cold deformation.

The technical result achieved by implementing the proposed model is that high dispersion and uniformity of the billet structure over the entire plane of its cross-section are ensured. At the same time, the steel HT process is characterized by high performance, low power consumption, and improved operational characteristics. The apparatus for spheroidization annealing regime determines the uniform distribution of cementite globules in the ferrite matrix, which means that it provides the necessary mechanical properties of the metal for its further cold deformation. In this case, the software of a multiprocessor computing system allows controlling the temperature conditions, both on the entire plane of the billet section, and along its length. Such temperature conditions are controlled in the plane center of the billet cross-section. Below is a general mathematical formulation of the problem. A multiprocessor computing system with special software, as a single base, includes mathematical models in the form of a heat equation, i.e.

$$
\frac{\partial T}{\partial \tau}=\frac{\partial^{2} T}{\partial z^{2}}+\frac{\partial^{2} T}{\partial r^{2}}+\frac{1}{r} \cdot \frac{\partial T}{\partial r}+W
$$

with the criterion $\tau=a t / R^{2}$ of Fourier, if $\tau>0, W$ considered as extraordinary power being the sources of the heat, $\mathrm{W} / \mathrm{m}^{2}$.

The boundary conditions of the equation are as the following.

$$
\begin{aligned}
& T(0, r, z)=f(r, \tau) \\
& T(\tau, 1, z)=\operatorname{var} ; \\
& \frac{\partial T(\tau, 0, z)}{\partial r}=0 ; \\
& T(\tau, 0, z) \neq 0 .
\end{aligned}
$$

The latter two equations in the boundary conditions depict that throughout the entire HT process, the temperature must be finite in the axis of the cylinder. According to the coordinate $z$, the boundary conditions, depending on the features of the problem to be solved, could be of the first, second, or third type. The problem (1) is solved using splitting methods, which aim is to simplify a sophisticated operator (1). This approach allows this equation integration in the form of an 
integration sequence of one-dimensional equations of a more simple structure. Given the significant complexity of the mathematical model (1), the development of the economic algorithms for computing the effects of controlling functions of the proposed installation is of great importance. The process of creating such algorithms is covered in papers [16 - 18].

Note that here the control problem (like the synthesis problem) in its exact statement refers to the inverse class since it provides for the determination of control functional parameters based on a predetermined and necessary result (the problem of inverse control). The algorithm of inverse problem solution uses the "fork" method with the preliminary definition of a particular initial segment. The solution to the problem is implemented in two stages. At first, there is the process of separating the residual minimum; at the second, the minimum of the desired control function from the separated interval is determined. The specified procedure is implemented as standard. In other words, if $\vartheta$ stands for a particular real value of the desired radical, i.e., when $a \leq \vartheta \leq b$, and $f(\vartheta)=0$, further, we could find the w number as such that satisfies the conditions: $a \leq \vartheta \leq b$ and $|\vartheta-w|<\varepsilon$, i.e., less than any predetermined small $\varepsilon$ number. The numerical control unit of the multiprocessor computing system includes a similar scheme in its structure. The mathematical model (1) is used in all HT cycles of metal; therefore, the simulation results relate to the primary metal heating cycle.

The simulation problem is that the necessary accuracy and computing stability requires taking a computation grid with a considerable number of nodes and do many iterations. As a result, the number of arithmetic operations necessary to compute the temperature fields is in the range of $10^{7}-10^{8}$ nodes, and when the time increment of $10^{-2}$ seconds, then the total nodes number for computations can grow up to at least to $10^{20}$. Single-processor computing systems can not cope with such a load throughout real-time simulation; hence, the multiprocessor systems will be most justified, which improves the technology of a long-steel product.

Experimental studies of HT of the metal products. In order to test the proposed installation functions, several experiments were performed when a $20 \mathrm{~mm}$ diameter wire from steel 20G2G was subjected to HT. Consider two unique experiences.

Experiment 1. ferritic-bainitic (martensitic) structure of the billet was taken as the initial. The process of the material heat treatment was run by heating the billet within the frames of the intercritical temperature zone. The following critical points are established: $\mathrm{Ac}_{1}=725^{\circ} \mathrm{C} ; \mathrm{Ac}_{3}=795^{\circ} \mathrm{C}$ for a given material. The heating was to such a value: $\mathrm{Ac}_{1}+\left(10-30^{\circ} \mathrm{C}\right)$. During the next stage of material processing, an isothermal holding was run for $45 \mathrm{~s}$. Further, the billet was getting cooled at a speed of $20-30^{\circ} \mathrm{C} / \mathrm{s}$ down to a temperature of $620^{\circ} \mathrm{C}$ followed by isothermal holding for 45 
s. In the end, at the last stage of material processing, the billet was heated at a rate of $15-25^{\circ} \mathrm{C} / \mathrm{s}$ to subcritical temperatures. A feature of controlling the billet temperature is to ensure the heating of its entire mass to the temperatures specified by a specific mode. The temperature distribution curves in the billet characterize the peculiarity of metal heating over the entire plane of its cross-section. Modeling of such temperature fields covers changes in the thermal physical properties of the material during its heating process. During the experiment, structure formation in billet material was analyzed. The structure is granular perlite with a standard 2 points score; its hardness is $148-169 \mathrm{HB}$.

So, the performed spheroidization of the metal carbide phase under the conditions of the corresponding HT regimes of the billet ensures the material with a granular perlite structure. Moreover, high-speed spheroidization determines a more uniform distribution of cementite globules in a ferrite matrix. Steel billets of almost the same hardness after the HT acquire a finely dispersed structure, which provides a higher level of ductility of the metal. Rapid billet heating and steel's partial austenitization, specific changes occur in the carbide phase morphology from the lamellar to the fine-grained globular.

Experiment 2. The ferrite-pearlite structure of the preform was taken as the initial one. The process of material HT was carried out according to the technology introduced in Experiment 1. For a given material, the following critical temperature points were established: $\mathrm{Ac}_{1}=725^{\circ} \mathrm{C}$ and $\mathrm{Ac}_{3}=795^{\circ} \mathrm{C}$.

During the study, a metallographic analysis of the billets structure was carried out. According to the official estimate, the grain microstructure of the billets is 5 points; its hardness is $150-169 \mathrm{HB}$.

Hence, the experiments showed that the initial structure of steel in a certain way affects the further structure formation and mechanical properties of the material.

\section{Conclusions and Prospects for Further Research}

The improvement of available and the developing of new technological processes for metal HT demand high costs on conducting a large number of fullscale experiments in the laboratory, experimental and industrial equipment, and in production conditions as well. Reducing experimental studies and multiprocessor computing systems can achieve the time spent to obtain necessary information for the design and implementation of technological developments. This paper develops a model to study the high-speed modes of HT of long products and metals manufacturing.

The introduction of the proposed model for recrystallization and spheroidizing annealing of calibrated steel made it possible: 
- to monitor the technological parameters of the HT metal conditions, in particular, the temperature in the center of the section of the metal product, which ensures the provision of the material with the necessary properties, along the entire plane of the section and across the length of the billet for its further cold deformation;

- by a multiprocessor computing system, to control the temperature of heating, holding and cooling along the entire plane of the billet section, thereby improving the quality indicators of heat-treated steel;

- reduce the process duration of the spheroidizing metal annealing;

- reduce power consumption;

- synchronize the technological process of metal HT with the technological process of fasteners manufacturing;

The developed approach implementation for metal HT, based on the use of a multiprocessor computing complex, creates the problem of matching the processors' capabilities and the network interface of a cluster system. Respectfully, promising further studies allow solving this problem with multiprocessor systems with processors of different types. Therefore, it is essential to derive analytical relations to establish the optimal number of nodes for the cluster system, considering the computing capabilities of specific processors.

\section{REFERENCES}

1. Ivaschenko, V., Alishov, N., Shvachych, G., Tkach, M.: Latest technologies based on use of highefficient multiprocessing computer systems. Journal of Qafqaz University. Mathematics and Computer Science. Baku, Azerbaijan. - Vol. 1. - Numb. 1: 44 - 51 (2015).

2. Ivaschenko, V., Shvachych, G., Tkach, M.: Prospects of network interface Infiniband in multiprocessor computer system for solving problems of calculations' area spreading. System technologies. - № 2(91). - Dnipropetrovs'k: 32 - 43 (2013).

3. Shvachych, G., Shmukin, A.: Features of designing parallel computational algorithms for PCs in heat and mass transfer problems. East European Journal of Advanced Technologies. 2 (8), pp. 42-4 (2004).

4. Shvachych, G., Shmukin, A.: On the concept of unlimited parallelism in heat conduction problems. East European Journal of Advanced Technologies. 3 (9), pp. 81-84 (2004).

5. Ivaschenko, V., Shvachych, G., Tkach, M.: Specifics of Constructing of Maximally Parallel Algorithmic Forms of the Solving of the Applied Tasks. System Technology: Regional Interuniversity Collection of Proceedings, 3 - 9, 91 (2014).

6. Dolzhenkov, I., Bolshakov, V, Dolzhenkov, V.: Equipment of thermal shops. - Dnepropetrovsk: PGASiA, 320 p., (2004).

7. Shvachych, G., Sobolenko, A., Sobolenko, A.: Investigation of the temperature regime of operation of annealing furnaces of mine type of wire riots. Theory and practice of metallurgy. No. 1. - S. 59 62 (2003).

8. Khasin, G., Dianov, A., Popova, T., Kukartseva, L., Shamov, A.: Electro-thermal treatment and warm drawing of steel. - G.: Metallurgy . - 152 p. (1984).

9. Bobylev, M., Grinberg, V., Zakirov, D., Lavrinenko, Yu.: Preparation of the structure during the electrothermal treatment of steels for the upsetting of high-strength fasteners. Steel. - No. 11. - S. 54 - 60 (1996). 
10.Zakirov, D., Bobylev, M., Lavrinenko, Yu., Lebedev L., Syuldin, V.: Patent of RF \#2137847, cl. C 21 D 1/32, C 21 D 9/60, C 21 D 11/00. Installation for heat treatment of calibrated steel. Patent holder: Open Joint-Stock Company Avtonormal. - No. 98117255/02; declared 09/16/1998; publ. 09/20/1999.

11.Dolzhenkov, I., Dolzhenkov, I.: Spheroidization of carbides in steel. - G .: Metallurgy. - p, 143 (1984).

12.Ivashchenko, V., Bashkov, E., Shvachych, G., Tkach, M.: Pat. 61944 Ukraine, IPC C21D 1/26 (2006.01), G06F 15/16 (2006.01). Installation for heat treatment of long-steel products. Owners: National Metallurgical Academy of Ukraine, Donetsk National Technical University. - No. u 201014225; declared 11/29/2010; publ. 08/10/2011, Bull. Number 15.

13.Ivaschenko, V., Shvachych, G., Sobolenko, A., Protopopov D.: Information system of intelligent support of decision-making for rolling process. Eastern-european journal of enterprise technologies. - № 3. - pp. 4-9 (2003).

14. Shvachych, G., Sobolenko, A., Protopopov, D., Chuev, A.: Information system for tracking a pipe rolling unit 140 with tandem conditions. Theory and practice of metallurgy. - No. 5-6. - pp. 76 - 82 (2003).

15.Shvachych, G., Kolpak, V., Sobolenko, M.: Mathematical modeling of high-speed modes of heat treatment of long products. Theory and practice of metallurgy. National scientific and technical journal. - No. 4-5 (59-60). - pp. 61 - 67 (2007).

16. Shvachych, G.: On the algebraic approach in the concept of distributed modeling of multidimensional systems. Theory and practice of metallurgy. - No. 6 (61). - pp. 73 - 78 (2007).

17. Shvachych, G.: Mathematical modeling of a class of problems of metallurgical thermophysics based on multiprocessor parallel computing systems. Mathematical modeling. - No. 1 (18). - pp. 60 -65 (2008).

18. Shvachych, G., Shmukin, A.: Some features of the design of algorithms for multiprocessor computing systems. Interstate Scientific-Methodological Conference "Problems of Mathematical Modeling”. - Dneprodzerzhinsk. - pp. 112 - 114 (2011).

Received 10.01.2020.

Accepted 17.01.2020.

УДК 004.272.43.003.13

В.П. Іващенко, Г.Г. Швачич, М.С. Сазонова, О.В. Запорожченко, В.І. Христян МОДЕЛЬ ТЕРМІЧНОЇ ОБРОБКИ МЕТАЛІВ

Серйозне скорочення лабораторних і дослідно-експериментальних досліджень можна здійснити шляхом розробки нових моделей термічної обробка металу на основі застосування багатопроцесорних обчислювальних комплексів. В даній роботі розглядається проблема розробки моделі теплової обробки металів на основі багатопроцесорних систем. Отриманий метал застосовується для виготовлення високоміцних кріпильних виробів методом холодного об'ємного штампування без завершуючої термічної обробки. В основу моделі покладено спосіб термічної обробки металу 3 низько- й середньовуглицевих сталей, призначених для холодної висадки. Застосування моделі має на меті поліпшення технологічних властивостей заготовок за рахунок забезпечення високої дисперсності й однорідності структури зразка за усією площиною його перерізу.

Технічний результат, який досягається при впровадженні запропонованої моделі, полягає в тому, що забезпечується висока дисперсність і однорідність структури зразка. Технологічний процес термічної обробки сталі характеризується високою продуктивністю, малим енергоспоживанням, поліпшеними 
експлуатаційними характеристиками. Застосування установки для реалізації режиму сфероїдизуючого відпалу зумовлює рівномірний розподіл глобул цементита у ферритной матриці, а значить забезпечує необхідні механічні властивості металу для його подальшої холодної деформації. Програмні засоби багатопроцесорної обчислювальної системи дозволяють контролювати температурні режими, як за усією площиною перерізу зразка, так і за його довжиною. Контроль таких температурних режимів здійснюється в центрі площини перерізу зразка.

Проведено експериментальні дослідження термічної обробки металовиробу. Для випробування функцій запропонованої моделі було проведено декілька експериментів, коли дріт діаметром 20 мм із сталі 20Г2Г піддавався термічній обробці. Експериментальні дослідження показали, що метал, зберігаючи необхідну твердість, має необхідні властивості еластичності. Крім того, проведені експерименти показали, що початкова структура сталі певним чином, впливає на подальше структуроутворення та механічні властивості матеріалу.

Ключові слова: термічна обробка, багатопроцесорна обчислювальна система, математична модель, контроль параметрів, технологічний процес, температурний режим.

Іващенко Валерій Петрович - доктор технічних наук, професор, перший проректор, Національна металургійна академія України, м Дніпро.

Швачич Геннадій Григорович - доктор технічних наук, професор, завідувач кафедри прикладної математики та обчислювальної техніки, Національна металургійна академія України, м Дніпро.

Сазонова Марина Сергіївна - кандидат технічних наук, доцент, доцент кафедри прикладної математики та обчислювальної техніки, Національна металургійна академія України, м Дніпро.

Запорожченко Олена Сергї̈вна - кандидат технічних наук, доцент, доцент кафедри інформаційних технологій, Університет ім. Альфреда Нобеля, м Дніпро.

Христян Володимир Іванович - старший викладач кафедри прикладної математики та обчислювальної техніки, Національна металургійна академія України, м Дніпро.

Иващенко Валерий Петрович - доктор технических наук, профессор, первый проректор, Национальная металлургическая академия Украины, г. Днепр.

Швачич Геннадий Григорьевич - доктор технических наук, профессор, заведующий кафедрой прикладной математики и вычислительной техники,

Национальная металлургическая академия Украины, г. Днепр.

Сазонова Марина Сергеевна - кандидат технических наук, доцент, доцент кафедры прикладной математики и вычислительной техники

Национальная металлургическая академия Украины, г. Днепр.

Запорожченко Елена Евгеньевна - кандидат технических наук, доцент, доцент кафедры информационных технологий, Унивенрситет имени Альфреда Нобеля, г. Днепр. 
Христян Владимир Иванович - старший преподаватель кафедры прикладной математики и вычислительной техники, Национальная металлургическая академия Украины, г. Днепр.

Ivaschenko Valery - Doctor of Technical Science, Professor, First Vice-Rector, National Metallurgical Academy of Ukraine, Dnipro.

Shvachych Gennady - Doctor of Technical Sciences, Professor, Head of the Department of Applied Mathematics and Computer Science

National Metallurgical Academy of Ukraine, Dnipro.

Sazonova Maryna - candidate of technical sciences, docent, docent of the Department of Applied Mathematics and Computer Science, National Metallurgical Academy of Ukraine, Dnipro.

Zaporozhchenko Olena - candidate of technical sciences, docent, docent of the Department of Information Technology, Alfred Nobel University, Dnipro.

Khristyan Volodymyr - Senior Lecturer of the Department of Applied Mathematics and Computer Science, National Metallurgical Academy of Ukraine, Dnipro, Ukraine. 